Research Article

\title{
Evaluation of stricture posterior urethra pre and post operatively with the help of retrograde urethrography with special reference to patient satisfaction
}

\author{
Rajkishore Singh $^{1 *}$, Rajesh Lonare${ }^{1}$, R. K. Mathur ${ }^{2}$, Arvind Ghanghoria ${ }^{2}$, Kulwant Singh ${ }^{1}$
}

${ }^{1}$ Department of Surgery, People's College of Medical Sciences \& Research Centre, Bhopal-462037, M.P., India
${ }^{2}$ Department of Surgery, MGM Medical College, Indore, M.P., India

Received: 28 April 2015

Revised: 10 May 2015

Accepted: 24 May 2015

\author{
*Correspondence: \\ Dr. Rajkishore Singh, \\ E-mail: ra5555@rediffmail.com
}

Copyright: () the author(s), publisher and licensee Medip Academy. This is an open-access article distributed under the terms of the Creative Commons Attribution Non-Commercial License, which permits unrestricted non-commercial use, distribution, and reproduction in any medium, provided the original work is properly cited.

\begin{abstract}
Background: Urethral Stricture is defined as decrease in the caliber of the urethra, due to scar resulting from tissue injury or destruction. The stricture of the posterior urethra involves membranous and prostatic urethra. Changes in urologic imaging are occurring at a rapid rate.

Methods: In this study, we evaluate the patient with posterior urethral stricture pre and post operatively with the help of retrograde urethrography with their satisfaction. We present our experience with 72 cases of posterior urethral stricture \& its management with the help of retrograde urethrography, for the last 10 years.

Results: All cases were male. Maximum age incidence is between 21-30 years age group i.e. 29 (40.27\%). 45 cases $(62.5 \%)$ were due to fracture pelvic and $20(27.78 \%)$ cases were due to previous catheterization. Average age was 33.79 years. Length of stricture was mostly $1-3 \mathrm{~cm}$. Average duration of follow up was 20.92 months. Outcomes in our series were good result in $49(68.05 \%)$, fair result in $20(27.78 \%)$ \& poor result in $3(4.16 \%)$ of the patients.

Conclusions: In this study, retrograde urethrography defines the extent and the location of the stricture pre operatively and then extent of correction after the operation in various patient.
\end{abstract}

Keywords: Posterior urethra, Stricture, Retrograde urethrogram, Membranous, Prostatic

\section{INTRODUCTION}

When all is said and done, the selection of operation is a highly individualized thing and the logic of the ultimate choice is summed up by the Turner Warwick TTTBAPJT Procedure (taking it to bits and putting it back together).

About $10 \%$ of all injuries seen in the emergency room involve the genitourinary system to some extent. ${ }^{1}$ Urethral injuries are uncommon and occur most often in men, usually associated with pelvic fractures or straddle type falls. ${ }^{2}$ Strictures represent a pathological narrowing of the urethral lumen, causing both anatomical and functional obstruction. ${ }^{3}$ Posterior urethral stricture is an obliterative process in the posterior urethra that has resulted in fibrosis and is generally the effect of distraction in that area caused by either trauma or radical prostatectomy. ${ }^{4}$ The classical triad of blood at the external urethral meatus, inability to pass urine and a distended bladder is good indicator of urethral injuries. Blood at the urethral meatus in men indicates urethral injury. ${ }^{5}$ Urethrography (Retrograde and Micturating urethrography), urethroscopy, flow rates urethrography defines the extent and the location of the stricture. An ascending urethrogram is the standard investigation. Various treatment option included in urethral stricture are 
dilatation, urethrotomy, excision \& end to end anastomosis, graph urethroplasty.

Although the urethral injury is seldom the main problem of these often multiply and severely traumatized patients, the consequences of the urethral trauma such as urethral strictures, erectile dysfunction, and (in some cases) urinary incontinence may be problems with life-long ramifications for the patients. ${ }^{6}$

\section{Aims \& objectives}

1. To determine the effectiveness of procedure done with the help of retrograde urethrography.

2. To ascertain the length of stricture in posterior urethra before operation.

3. To get RCU done again after operation to know extent of stricture corrected and to assess the benefit of different procedure to the patient.

\section{METHODS}

The study is aimed at evaluation of stricture posterior urethra pre and post operatively with the help of retrograde urethrography with special reference to patient satisfaction. This study include all the 72 cases of posterior urethral stricture in M.Y. Hospital, Indore both pre and post operatively for the period of last 10 years.

The detailed history and physical examination was carried out. AUA Scores assessed and dye studies done both pre and post operatively. Then patient satisfaction noted both objectively and subjectively. Mainly retrograde urethrography done combined with MCU (Micturating cysto urethrography) to aid the precise anatomy and character of stricture. Then after operation retrograde urethrography again done to reassess the anatomy and stricture corrected.

\section{Retrograde urethrogram}

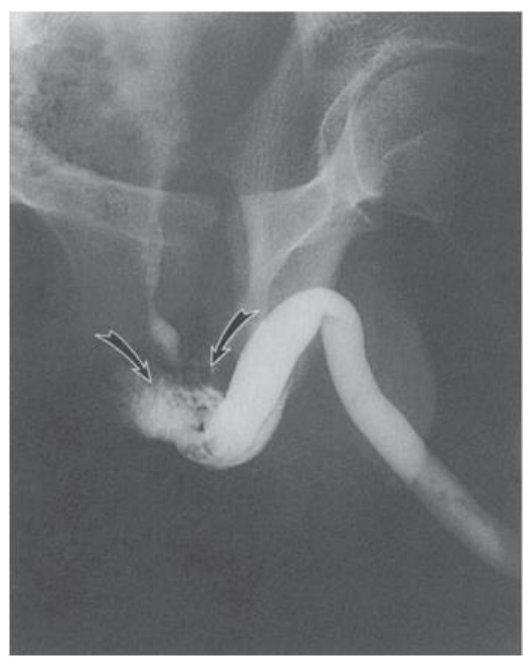

Figure 1: Ruptured urethra. Extravasation of contrast medium around the membranous urethra (arrows).
It is an invaluable test to evaluate and document the stricture (Figure 1). Performed as an out-patient X-ray procedure and can indicate the number, position length and severity of stricture. It involves insertion of contrast dye into the urethra at the tip of the penis.

\section{Operative technique}

Perineal repair of stricture of membranous urethra:

Inverted "Y" shaped incision from midline of the scrotum to ischial tuberosities given, then Colle's Fascia opened to expose the bulbospongious muscles \& dissected the corpora spongiosum from urogenital diaphragm. Space created between muscles \& the bulb of the urethra. Bulbospongiosum is mobilized to gain access to the strictured membranous urethra. Strictured segment resected \& freeing the bulb of the urethra. Urethra opened dorsally showing an adequate lumem (Figure 2). A sound is passed through the suprapubic cystostomy and resection of scar allows to pass into the perineum. A silicon catheter then passed into the bladder and anastomosis complete in "U" shape. Wound closed in layers.

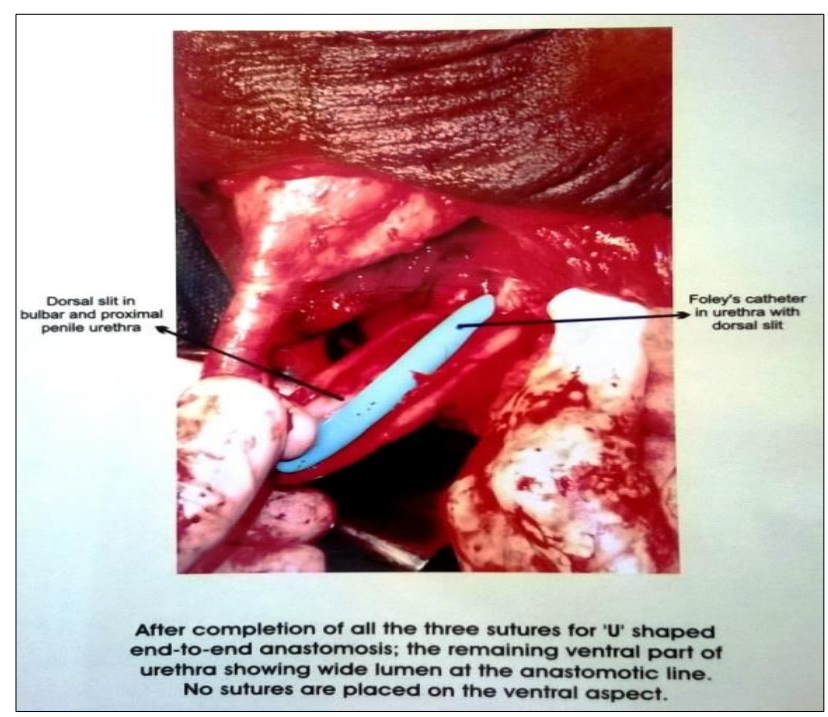

Figure 1: Demonstrate the steps and anastomosis of membranous urethra.

\section{RESULTS}

Data from 72 patients of posterior urethral stricture were reviewed on the basis of retrograde urethrogram pre \& post operatively. In our study all the cases were male. Maximum age incidence is between 21-30 years age group i.e. $29(40.27 \%)$. Out of these 45 cases $(62.5 \%)$ were due to fracture pelvic and $20(27.78 \%)$ cases were due to previous catheterization. Teenagers in this series formed $10(13.89 \%)$ of the total cases and average age was 33.79 years. Two patients $(2.78 \%)$ were congenitally dead \& dumb. Table 1 displays the length of posterior urethral stricture in our series. 
Table 1: Showing length of posterior urethral stricture.

\begin{tabular}{|lll|}
\hline $\begin{array}{l}\text { Length of } \\
\text { stricture }(\mathbf{c m})\end{array}$ & \multicolumn{2}{l|}{ Total member of cases } \\
\hline $0-1$ & 8 & 11.11 \\
\hline $1.1-2.0$ & 31 & 43.06 \\
\hline $2.1-3.0$ & 21 & 29.16 \\
\hline $3.1-5.0$ & 12 & 16.66 \\
\hline
\end{tabular}

In our series the duration of postoperative catheterization was 21-24 postoperative days for $60(83.33 \%)$ patients. The catheter had to be kept for a longer duration in case of wound infection in other patients, i.e. 12 (16.67\%). The following Table 2 shows the stricture segment on retrograde urethrogram (pre operatively).

Table 2: Showing stricture segment on retrograde urethrogram (pre operatively).

\begin{tabular}{|lll|}
\hline Stricture segment & $\begin{array}{l}\text { No. of } \\
\text { cases }\end{array}$ & $\begin{array}{l}\text { \% of } \\
\text { cases }\end{array}$ \\
\hline SMU & 39 & 54.16 \\
\hline SMU+SPU & 9 & 12.5 \\
\hline SMU+SBU & 20 & 27.77 \\
\hline SMU+SBU+SPNU & 3 & 4.16 \\
\hline SMU+SBU+SPU & 1 & 1.39 \\
\hline
\end{tabular}

The Follow up varied from 1 to 95 months and the average duration of follow up was 20.92 months. Table 3 displays the condition of urethra postoperatively on retrograde urethrogram.

Table 3: Showing urethra postoperatively on retrograde urethrogram.

\begin{tabular}{|lll|}
\hline Urethra & $\begin{array}{l}\text { No. of } \\
\text { cases }\end{array}$ & $\begin{array}{l}\% \text { of } \\
\text { cases }\end{array}$ \\
\hline Normal & 58 & 80.55 \\
\hline SPU & 1 & 1.39 \\
\hline SPU+SMU & 1 & 1.39 \\
\hline Not done RCU & 12 & 16.67 \\
\hline
\end{tabular}

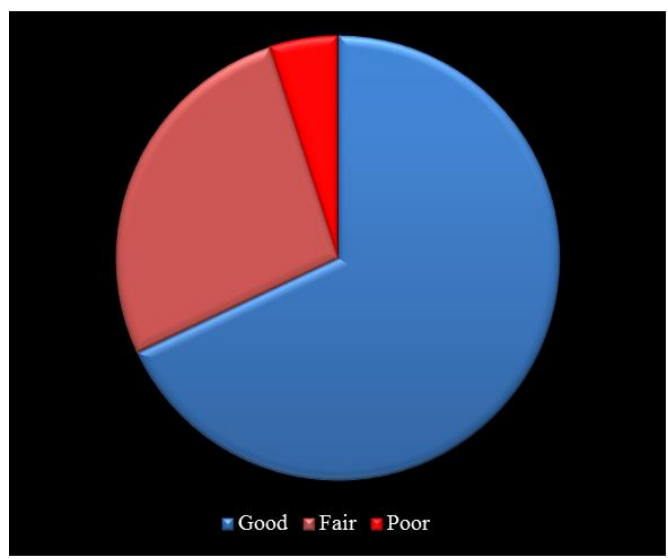

Figure 2: Depicting the post-operative result.
In the follow up strategy 8 patients $(11.11 \%)$ found to be impotent, $7(9.72 \%)$ of these were temporarily and 1 $(1.39 \%)$ was permanently impotent. Figure 3 displays the pie chart of the outcomes in our series i.e. Good result in $49(68.05 \%)$, Fair result in $20(27.78 \%)$, Poor result in 3 $(4.16 \%)$ of the patients.

13 patients (18.05) did not required postoperative dilatation, $7(9.72 \%)$ patients required once and rest were required 2 to 8 monthly dilatation. $7(9.72 \%)$ patients had to undergo DVIU since they were requiring monthly dilatation. The interval between suprapuble cystostomy and urethroplasty in patients with pelvic trauma varied from 15 days to 5 years with a mean of 7.13 months

\section{DISCUSSION}

The management of posterior urethral stricture is one of the most difficult surgical problem faced by a urologist. It is an uncommon injuries at an inaccessible location. Urethral injury is usually secondary to blunt trauma, occurring in 5 to $10 \%$ of cases of pelvic fracture.

Pelvic injury use to occur in all age so the stricture urethra is seen in all age groups. An average age of 35.8 years reported by B. Mucha et al., ${ }^{7}$ and B. Fellon et al. ${ }^{8}$ reported peak age incidence of pelvic injuries was 10-40 years age $(61 \%)$ of patients. This peak age incidence is comparable with that in our study i.e. 21-40 years $(61.29 \%)$ of patients. All the cases in this series were male because of its short length and relative mobility, injuries to the female urethra is extremely rare. Acquired urethral stricture is common in men but rare in women. ${ }^{9}$

In this series there are 45 patients $(62.50 \%)$ with pelvic trauma, this can be explained by the fact that road traffic accidents resulting in pelvic trauma are more common on our roads, whereas A. R. Mundy in his series of 200 patients the post pelvic fracture patients were $86(43 \%){ }^{10}$ In posterior urethral injuries resulting from pelvic trauma the most common site of rupture is at the bulbomembranous urethral junction ( Spimak $^{11}$ ) which is in concordance with our current study. Distraction injuries are for all intents unique to the membranous urethra. $^{12}$

The urethral disruption in pelvic fracture occurs due to tearing of urethra at the inferior surface of the urogenital diaphragm, as the prostate, membranous urethra and urogenital diaphragm, all forms an anatomic unit, so in case of pelvic trauma the stricture in membranous urethra were of $1-3 \mathrm{~cm}$ in length. The stricture due to instrumentation occurs as a result of infection which produces wide spread scarring and hence, longer structures. Anastomotic repair required 2 to 3 weeks of stenting. This is in concordance with postoperative catheterization in our series. In case of urethrocutancous fistula or other infection the indwelling silicon catheter have to kept for a longer duration. 
The average period of follow up in our series was 17.05 months which is comparable with other series like Abrahans et al. 9-36 months, ${ }^{13}$ Mckinney's et al. 4-24 months. ${ }^{14}$ The impotence rate in our series was found to be $11.29 \%$ which is in concordance with other studies. The patient may be impotent for several months after delayed repair. Impotence is permanent in about $10 \%$ of patients. ${ }^{15}$ Dixon et al. ${ }^{16}$ presented evidence that impotence may be a consequence of the avulsion of the corpora cavernosa from the ischium. Lesser impotence rate is associated with delayed primary repair, which is in concordance with our series $(11.29 \%)$.

Our study shows $69(95.83 \%)$ cases of combined good and fair result, with $3(4.17 \%)$ observed poor result. The criteria for assessment of postoperative results are shown in Table 4.

Table 4: Showing urethra postoperatively on retrograde urethrogram.

\begin{tabular}{|llll|}
\hline $\begin{array}{l}\text { Postoperative } \\
\text { urethrogram }\end{array}$ & $\begin{array}{l}\text { urethra with uniformly good } \\
\text { caliber }\end{array}$ & $\begin{array}{l}\text { Fair } \\
\text { Urethra with some narrowing } \\
\text { and irregularity }\end{array}$ & $\begin{array}{l}\text { Urethra with very narrow } \\
\text { lumen }\end{array}$ \\
\hline $\begin{array}{l}\text { Patients } \\
\text { satisfaction } \\
\text { rate }\end{array}$ & $\begin{array}{l}\text { Passing urine per urethrally } \\
\text { in good stream }\end{array}$ & $\begin{array}{l}\text { Passing urine per urethrally } \\
\text { with slightly weak stream but } \\
\text { happy that he is passing urine } \\
\text { per urethrally }\end{array}$ & $\begin{array}{l}\text { Weak stream with straining } \\
\text { of not passing urine per } \\
\text { urethrally at all }\end{array}$ \\
\hline AUA score & $0-7$ & $8-19$ & $20-35$ \\
\hline
\end{tabular}

In our series the cause of high percentage of good and fair results are perineal approach and delayed primary repair. Our results are as similar with Webster George et al. ${ }^{17}(97.26 \%)$ and A. R. Mundy ${ }^{18}(88 \%)$, F. Morey ${ }^{19}$ $(97 \%)$ result of success. Patients who had initial realignment procedure like real roading and delayed urethroplasty had associated with more chances of restenosis, Impotence or Incontinence.

In another study (Morey \& McAnninch) the incidence of erectile dysfunction was repoarted as up to $55 \%$ after immediate realignment, ${ }^{20}$ similarly immediate repair associated with poor results with high incidence of subsequent stricture, incontinence and impotence, this is because of active bleeding, hematoma and oedema. There is a widespread acceptance of a 'hands-off 'policy in the acute management of posterior urethral injury. ${ }^{21}$

A. R. Mundy stated that the greater the interval between suprapubic cystostomy and urethroplasty or DVIV, the better one the outcome resulting potency and continence. $^{22}$ This is in concordance with the result in our series.

In conclusion, Turner Warwick has described the problem accurately. "It is the urologist who will have to share the burden of the ultimate disability with the patient when the thoracic, abdominal and even the orthopedic aspects are probably long forgotten". We conclude that procedure selection should be determined by stricture characteristic, including location, etiology, length and the presence of local adverse factors. An overall rate free of stricture of $95.10 \%$ was achieved.

\section{ACKNOWLEDGMENTS}

The authors acknowledge the assistance of Mukesh Lonare, Gaurav Shakya for help in the preparation of this article.

Funding: No funding sources

Conflict of interest: None declared

Ethical approval: The study was approved by the institutional ethics committee

\section{REFERENCES}

1. Jack W. McAninch. Injuries to the genitourinary tract. In: Jack W, McAninch, eds. Smith's General Urology. 17th ed. New York: McGraw-Hill Medical; 2008: 278.

2. Jack W. McAninch. Injuries to the genitourinary tract. In: Jack W, McAninch, eds. Smith's General Urology. 17th ed. New York: McGraw-Hill Medical; 2008: 291.

3. Joe J. Tjandra, Gordon J.A. Clunie, Andrew H. Kaye, Julian A. Smith. Urethral injuries. In: Joe J. Tjandra, Gordon J.A. Clunie, Andrew H. Kaye, Julian A. Smith, eds. Textbook of Surgery. US: Wiley-Blackwell; 3rd ed. 2006: 518.

4. Wein AJ, Kavoussi LR, Novick AC, Partin AW, Peters CA. Urethral stricture disease. In: Wein AJ, Kavoussi LR, Novick AC, Partin AW, Peters CA, eds. Campbell-Walsh Urology. 9th ed. Philadelphia: Saunders; 2007: Chapter 33.

5. Jack W. McAninch. Injuries to the genitourinary tract. In: Jack W, McAninch, eds. Smith's General Urology. 17th ed. New York: McGraw-Hill Medical; 2008: 278. 
6. Schreiter F, Schönberger B, Olianas R. Reconstruction of the bulbar and membranous urethra. In: Schreiter F, Schönberger B, Olianas R, eds. Advanced Urologic Surgery. 3rd ed. US: Wiley-Blackwell; 2005: 217.

7. B. Mucha Peter, Farnell Micheal. Analysis of pelvic fracture management. J Trauma. 1984;24(5):379-85.

8. Fellon B, Wendt JC, Howetrey CE. Urological injury and assessment in patients with fractured pelvis. J Urol. 1984 Apr;131:712-3.

9. Jack W. McAninch. Disorders of the penis \& male urethra. In: Jack W. McAninch, eds. Smith's General Urology. 17th ed. New York: McGraw-Hill Medical; 2008: 633.

10. Mundy AR. Pelvic fracture injuries of the posterior urethra. World J Urol. 1999;17:90,95.

11. Spimak JP, Smith EM, Elder JS. Posterior urethral obliteration treated by endoscopic reconstitution, internal urethrotomy and temporary self-dilation. J Urol. 1993;149:766.

12. Wein AJ, Kavoussi LR, Novick AC, Partin AW, Peters CA. Urethral Injuries, posterior urethra. In: Wein AJ, Kavoussi LR, Novick AC, Partin AW, Peters CA, eds. Campbell-Walsh Urology. 9th ed. Philadelphia: Saunders; 2007: Chapter 33.

13. Abrahans SA, Parra RO. Treatment of posttraumatic urethral obliteration; experience in 396 patients. J Urol. 1995;153:67.

14. Mckinney JW. Traumatic injuries to the urethra. J Trauma. 1981;21:291.

15. Jack W. McAninch. Injuries to the genitourinary tract. In: Jack W. McAninch, eds. Smith's General Urology. 17th ed. New York: McGraw-Hill Medical; 2008: 293.
16. Gosling JA, Dixon DS. The structure and innervation of smooth muscle in the wall of the bladder neck and proximal urethra. $\mathrm{Br} \mathrm{J}$ Urol. 1975;47:549.

17. Webster GD, Mathes GL, Selli C. Prostatomembranous urethral injuries. A review of the literature and a rational approach to their management. J Urol. 1983;130:898-902.

18. Mundy AR. Results and complication of urethroplasty and its future. Br J Urol. 1993;71:3225.

19. Morey AF, McAninch JW. Reconstruction of posterior urethral disruption injuries: outcome analysis in 82 patients. J Urol. 1997;157:506-51.

20. Morey AF, McAnninch JW. Reconstruction of posterior urethral disruption injuries: outcome analysis in 82 patients. J Urol. 1997;157(2):506-10. Schreiter F, Schönberger B, Olianas R. The urethral disruption. In: Schreiter F, Schönberger B, Olianas R, eds. Advanced Urologic Surgery. 3rd ed. US: Wiley-Blackwell; 2005: 217.

21. Schreiter F, Schönberger B, Olianas R. Reconstruction of the bulbar and membranous urethra. In: Schreiter F, Schönberger B, Olianas R, eds. Advanced Urologic Surgery. 3rd ed. US: Wiley-Blackwell; 2005: 217.

22. Mundy AR. The role of delayed primary repair in the acute management of pelvic fracture injuries of the urethra. Br J Urol. 1991;68;273-6.

Cite this article as: Mishra P, Patni D, Kaushik M, Dehadaray A. Evaluation of stricture posterior urethra pre and post operatively with the help of retrograde urethrography with special reference to patient satisfaction. Int Surg J 2015;2:361-5. 